\title{
Two Dantes or One? An Essay in Transcendence and Theatricality
}

Dante was attached, simultaneously, to Christianity and to paganism. This was not a half-way position, nor a wavering between two conceptions of life according to mood or circumstance. The attachment to paganism was more like that which a man may feel to his youth, except that paganism was a stage in the history of Dante's race, not of himself individually. Yet there is a sense in which the pagan 'object' of his attachment was not something past and done with, existing only in history or legend or works of art; rather it was a permanent part of himself, an alter ego; it was that second self which his imagination took into the Other World in the form of Virgil and which, once it had assumed this form, was allowed to take charge of, to guide and govern the Christian protagonist of the resulting poem. ${ }^{1}$

1. Introduction: ego, alter ego and the problem of authorial intentionality - a preliminary response. 2. Piety, Peripateticism and sin as unreason: 'The Theology of the Inferno'. 3. Irreconcilability in the depths: 'The Two Dantes'. 4. Two Dantes or one?: dimensionality, decorum and the comprehensive geometry of the text.

Kenelm Foster's tripartite essay on the two Dantes, published in 1977, represents a point of arrival in respect of a lifelong meditation on the issues it raises, on, as he himself saw it, the co-presence in Dante of orders of philosophical and theological concern never quite reconciled

${ }^{1}$ Kenelm Foster, O.P., 'The Two Dantes (I)', in The Two Dantes (London: Darton, Longman and Todd, 1977), p. 156. 
one with the other or brought home to a unified and internally consistent spirituality. Encouraged as he was by the massive and massively erudite initiative of Bruno Nardi and of Etienne Gilson, responsible between them for rescuing Dante from those who would see in him a more or less fully professed Thomist, ${ }^{2}$ and coming to Dante as he did from the point of view of one committed by profession to the Thomist way in philosophy and theology, he was more than ordinarily sensitive to what in Dante amounts to the difficulty of his particular kind of bi-culturalism, to his living out at one and the same time the exigencies both of a Christian and a Peripateticizing conscience. But for all his insight and tact in seeing and setting up the question, Kenelm's sense of the alterity of it all - certainly if by this we mean the survival into the Commedia of distinct and mutually irreducible egos, of a Christian and of a pagan ego - is open to question; for decisive as the idea is for the moments of Dante's meditation represented by the Convivio and the Monarchia as committed to the resolution of high-level issues in the areas of moral philosophy and of political theology, there are forces at work in the Commedia tending to soften and ultimately to liquidate the kind of alternativism which Kenelm Foster sees as a dominant feature even here of Dantean spirituality. On the one hand, then, there are the theological forces whereby each successive emphasis in the areas both of moral and of natural philosophy is rendered transparent to the innermost reasons of the text as a product of Christian piety, while on the other hand there are the theatrical forces whereby those same emphases, distributed among the poem's players such that each only ever speaks in character, serve merely to confirm its consistency

${ }^{2}$ Kenelm on Nardi and Gilson, on Dante and Thomism, and on his own sense of the 'humanistic' problem in Dante: 'This question of the continuity of the Comedy with the minor works was a good deal debated by Dante scholars in the 1940 s and ' 50 s. As I had occasion to write some years ago and feel able to repeat today, "after Nardi's and Gilson's work in the 1930s it had become evident that Dante could no longer be called a Thomist without very considerable qualifications; and in particular that the Convivio and the Monarchia show clear traces of a certain dualism - in assertions, more or less explicit, of the independence of philosophy from theology and of the civil power from the Church, and of the twofold 'final end' of man ... The question then arose whether this dualism persisted into the Comedy, and if so precisely to what effect; the result being ... to concentrate attention on the contrasted symbols of Virgil and Beatrice, and more generally to raise the issue of the 'humanism' or otherwise of the Comedy". This was written when I was still inclined to date the Monarcbia before the Comedy: yet I would still maintain that there is a fundamental difference ... between the Comedy and the two other works taken together. This seems to me clear even supposing that the Monarchia belongs to the last decade of the poet's life and that doctrinally there is agreement between it and the Comedy where both works touch on the same themes'. (ibid., pp. 163-64; the reference here is to his piece entitled 'Dante Studies in England, 1921-64', Italian Studies 20 (1965), 7). 
at the level of authorial intentionality. Now Kenelm, whose inclination was always to turn back upon the leading proposition with a view to its further refinement, would himself have gone along with this, for his too was a sense both of the maturity of the Commedia in its bringing home of each subsequent inflexion of the spirit to its depth-dimensionality and of its decorum, its proportioning of each subsequent intervention in the text to the properties of personality. But this, when it comes to the valedictory statement, is not what he chooses to emphasize. Rather, it is a question as far as the Commedia is concerned of irresolution and of the melancholy thereof, of a work which, for all its perspectivization both of the moral and the political issues upon which it touches, remains less than equal to the restiveness of its cultural premises.

2. One of Kenelm's earliest accounts of the rationalist or (as he himself used to say) the 'humanistic' component of Dante's thought tending even in the Commedia to subsist over against its theological component comes in his essay 'The Theology of the Inferno' published in 1957 as part of the volume entitled God's Tree: Essays in Dante and Other Matters, an initiative predating the Two Dantes, therefore, by twenty years. ${ }^{3}$ Setting out to explore the theological programme of the Inferno, but also to call into question its status as a stable expression of the Catholic mind, the essay begins by noting that Dante's genius in the Commedia can be admired in the wrong way; for Dante, Kenelm maintains, was not really a theologian at all. Enamoured as he was of theology, and given to searching her somewhat after the manner of a lover, he was first and foremost a maker of images, his, therefore, as far as theology is concerned, being something closer to 'usage' - Gilson's 'usage défini' - than to anything more professional or systematic:

Again, his great intellect can be admired in the wrong way: Dante did not put the Summa theologiae into verse, for he could not possibly have put it into prose. The epitaph composed by Giovanni di Virgilio, “Theologus Dantes" etc., cannot, as M. Gilson has said, be taken à la lettre. It might be less misleading to deny that Dante was a theologian; it is safer to call him a magnificent amateur. Essentially he was a poet, a maker of images, using doctrine poetically, searching it as a lover. His speculative enthusiasm was superbly pure and strong, but it ran in certain directions. So Dante's teaching remains a selection, as it were, within the doctrinal materials at his disposal. Of these, as Gilson says, he made a certain usage défini. (pages 50-51)

${ }^{3}$ God's Tree. Essays on Dante and Other Matters (London: Blackfriars Publications, 1957), with 'The Theology of the Inferno' at pp. 50-66. 
The passage is problematic. It is problematic in respect (a) of the 'for he could not possibly have put it into prose' formula with which it begins (for it is a question here, not of power, but of preference, not of Dante's being unable to pursue the theological project in the way Thomas had, but of his not wishing to), and (b) of its sense of Dante as but a 'magnificent amateur' in theology, a way of putting it which, whether or not acceptable at the time of God's Tree, smacks nowadays of a certain cultural 'incorrectness', a certain lack of tact when it comes to our now revised sense of poetry and the theological project. ${ }^{4}$ True, Dante was no Thomas, the Commedia lacking the power of the great summae to systematic awareness, to an orderly statement of the theological situation in its totality. But by the same token Thomas was no Dante, the great summae lacking the power of the Commedia to engender a sense of the ontological agony and ecstasy of it all, to take us into'the deepest places of human self-destruction and despair as well as the highest places of courage and salvation,, ${ }^{5}$ at which point 'magnificent amateurism' as a way of describing Dante's intervention commends itself only for its inadequacy to the business in hand. Be that as it may, however, the way is now open, Kenelm thinks, for a critique of his sense of moral evil in the Inferno; for Dante's, he says, was everywhere a tendency, and a none too healthy one at that, to rely on reason alone as the way of getting to grips with this issue:

This need for clear knowledge was of course innate in Dante; but it was also in this case in line with his principles. He thought that he could pretty thoroughly know evil, and this in virtue of his human reason alone - aided of course by Aristotle's. The mind of Aristotle, indeed, had explored most of the manifestations of human vice. In Dante's view (it seems) the Inferno, considered simply as a lecture on human depravity, did not say very much more than the Nicomachean Ethico. He does not seem perhaps to have very keenly appreciated the enormous difference that Christianity had in fact made: he sees his Inferno mainly as an outline of human evil drawn by human wit. Unlike the Paradiso it contains, as he presents it, little that cannot be understood. It unveils iniquity. (p.51)

Evil, then, as envisaged by Dante in the Inferno, appears to be no more than an affront to right reason, to the customary co-ordinates of Peripatetic consciousness, with the result, Kenelm goes on, that the

${ }^{4}$ Recently on the relationship in Dante of the idea and the image, F. Livi, Dante e la teologia. L'immaginazione poetica nella 'Divina Commedia' come interpretazione del dogma, (Rome: Casa Editrice Leonardo da Vinci, 2008); V. Montemaggi and M. Treherne (eds), Dantés 'Commedia'. Theology as Poetry (Notre Dame, Ind.: University of Notre Dame Press, 2010).

${ }^{5}$ Paul Tillich, The Courage To Be (Collins: Glasgow, 1962; originally 1952), p. 128. 
sinners in Dante's hell 'would be sinners in any world that is human at all':

For my present purpose, however, the chief interest of Limbo is that it points to the very natural or rational character of the Inferno as a whole. For, as a vice is understood in terms of the contrary virtue, so it is the virtue of the great pagans in Dante's Limbo which implicitly (though I do not say the poet intended this) sets the standard by which most of the other inhabitants of Hell have failed to live, and, failing, have incurred damnation. I say 'most' of these, because the Heretics and Simonists, at least, are exceptions; they are Christian sinners, in the sense that their sins presuppose a Christian world. But most of the damned appear to have sinned against the norm of reason, the regula rationis, rather than against that regula divinae legis which St Thomas distinguished from it. They would be sinners in any world that is human at all. (p.54)

Again, the passage, is problematic, for quite apart from the propriety of - at any rate without ado - talking about 'sin' in anything other than a specifically Christian context, the question arises as to how far it can be thought of as a matter merely of irrationality or of unreasonableness. Irrationality and unreasonableness enter into it, but the term 'sin' connotes something both more and other than this, something closer to dividedness, and thus to Godlessness, at the point of willing, by which stage Aristotle and the Ethics have been left far behind. And this, as his essay goes on, is Kenelm's own sense of it, evil, he says, amounting to nothing but ingratitude in respect of the goodness which is God:

Love then is the reflection in creatures of the divine Unity and also the response to the divine Goodness reflected in creatures. The same God is reflected, from our point of view, twice over; and the one reflection (that of Unity) appears as tending to the other (that of Goodness). And since it is one God who is twice reflected, these two reflections - love derived from Unity and goodness derived from the Good - are ultimately the same; and it will be equally true to say that love pursues goodness and goodness pursues love: in short, that love loves love. That is why, in the last resort, the violation of goodness (i.e. evil) is the refusal of a lover, is ingratitude.' (p.62; italics original).

This notwithstanding, however, his even so remains a 'humanistic' account of what is going on in the Inferno, an account turning less on the notion of dividedness in the depths than on that of unreason on the surface, at which point the tragedy of it all - the tragedy of unreason as but a consequence of man's first disobedience - disappears from view. 
3. This, then, is where Kenelm begins in the 'The Two Dantes' essays of 1977, his sense of the intractability of it all, of Dante's entertaining in one and the same moment both the pagan and the pious, having if anything sharpened in the meantime. The opening sequence of the first essay, unsurpassed in the Dante literature of the English-speaking world for its quiet combination of tact and precision, sets up the question. Dante's, Kenelm says, was a living-out in his own person of the great phases of world history, his capacity for rejoicing in its successive moments, however, issuing in a spirituality never wholly at one with itself, never wholly settled in point of root intentionality. Reproduced in part at the head of this essay, the passage in question is worth reading over in full:

Dante was attached, simultaneously, to Christianity and to paganism. This was not a half-way position, nor a wavering between two conceptions of life according to mood or circumstance. The attachment to paganism was more like that which a man may feel to his youth, except that paganism was a stage in the history of Dante's race, not of himself individually. Yet there is a sense in which the pagan 'object' of his attachment was not something past and done with, existing only in history or legend or works of art; rather it was a permanent part of himself, an alter ego; it was that second self which his imagination took into the Other World in the form of Virgil and which, once it had assumed this form, was allowed to take charge of, to guide and govern the Christian protagonist of the resulting poem. Because the hero of the Divine Comedy is a Christian the poem is Christian, but through two-thirds of it the hero is guided by a pagan. And even 'guided' is too weak a term; Virgil in the poem is the hero's 'leader', 'master' , 'teacher', 'lord'. Above all he is Dante's 'father' - 'my sweet father', 'sweet and dear father', 'my more than father'. Seldom in literature has the filial sentiment, blending reverence and affection, been so finely expressed as in this relationship which carries the central narrative line through so much of the great poem. And it is of its essence that the father here is a pagan, the son a Christian; simultaneously so close and so separated. (page 156)

Wedded in one and the same moment both to Christianity and to paganism, the latter subsisting as an alter ego or alternative presence in the world, Dante's was a simultaneous commitment $(a)$ to the need for grace as that whereby man as man comes home to God as the beginning and end of his happiness, and (b) to the possibility even so of his affirming himself, albeit within certain clearly defined limits, by way of the ordinary processes of seeing, understanding and choosing, each of these things, however, - the grace-theological and the moral-philosophical - forever 
vying one with the other and seeking the upper hand. At once a principle and a product of this situation, Kenelm thinks, is his treatment of the noble pagans of antiquity, of those who, knowing not the Christ, are nonetheless confirmed in a state, not of atrocious, but of attenuated suffering, in the melancholy of unfulfilled because unfulfillable yearning. ${ }^{6}$ How, then, are

${ }^{6}$ In addition to the commentaries on Inferno IV and on the Dantean limbo, C. Grabher, 'Il Limbo dantesco e il nobile castello', Studidanteschi 29 (1950), 41-60; A. Camilli, 'La teologia del Limbo dantesco', Studi danteschi 30 (1951), 209-14; F. Montanari, ad voc. 'Limbo', in the Enciclopedia dantesca, 6 vols (Rome: Istituto della Enciclopedia Italiana, 1970-78), vol. 3, pp. 651-54; F. Forti, 'Il Limbo e i Megalopsicoi della “Nicomachea”', in Magnanimitade. Studi su un tema dantesco (Bologna, Pàtron, 1977), pp. 9-48; G. Padoan, 'Il Limbo dantesco', in Il pio Enea, l'empio Ulisse: Tradizione classica e intendimento medievale in Dante (Ravenna: Longo, 1977), pp. 103-24 (originally in Lettere Italiane 21 (1969), 4, 369-88); A. A. Iannucci, 'Limbo: the Emptiness of Time', Studi Danteschi 52 (1979-80), 69-128; idem, 'Il limbo dei bambini', in Sotto il segno di Dante. Scritti in onore di Francesco Mazzoni, ed. L. Coglievina and D. De Robertis (Florence: Le Lettere, 1998), pp. 153164; idem, 'Dante's Limbo: at the Margins of Orthodoxy', in Dante and the Unorthodox: The Aesthetics of Transgression, ed. by J. L. Miller (Waterloo (Ontario-Canada): Wilfrid Laurier University Press, 2005), pp. 63-82; F. Giardinazzo, 'La passione dell'intelligenza nel limbo dantesco', in Cercare il volume. Studidanteschi (Rimini: Guaraldi,1998), pp. 89112; M. P. Stocchi, 'Canto IV. A Melancholy Elysium', in Lectura Dantio. Inferno. A Cantoby-Canto Commentary, ed. by A. Mandelbaum et al. (Berkeley: University of California Press, 1998), pp. 50-62; F. Tateo, 'Figure della didattica e canoni della cultura antica nel limbo dantesco', in Studi sulla tradizione classica per Mariella Cagnetta, ed. L. Canfora (Rome and Bari: Laterza, 1999), pp. 507-24 (subsequently 'Gli antichi a confronto (If. IV)' in Simmetrie Jantesche (Bari: Palomar, 2001), pp. 13-34); G. C. Alessio, 'Il canto IV dell' Inferno', in Regnum celorum vïolenza pate. Dante e la salvezza dell'umanità. Letture Dantesche Gübilari, Vicenza, October 1999 - June 2000, ed. G. Cannavò (Montella, Avellino: Accademia Vivarium Novum, 2002), pp. 37-56. On Dante and pagan salvation, F. Ruffini, 'Dante e il problema della salvezza degli infedeli', Studidanteschi 14 (1930), 79-92; B. Quilici, Il destino dell'infidele virtuoso nel pensiero di Dante (Florence: Ariani, 1936); G. Busnelli, 'La colpa del "non fare" degl'infedeli negativi', Studidanteschi 23 (1938), 79-97; C. Filosa, 'La "virtù" dei romani nel giudizio di S. Agostino e di Dante', in Attidel congresso internazionale di Studi Danteschi, Roma 8-10 aprile 1965 (Florence: Le Monnier, 1965), pp. 195-210; G. Rizzo, 'Dante and the Virtuous Pagans', in W. De Sua and G. Rizzo (eds), A Dante Symposium in Commemoration of the 700th Anniversary of the Poet's Birth (1265-1321) (Chapel Hill: University of North Carolina Press, 1965), pp. 115-40; G. Cambon, 'Dante's Noble Sinners: Abstract Examples or Living Characters?', in Dante's Craft. Studies in Language and Style (Minneapolis: University of Minnesota Press, 1969), pp. 67-79; T. O'H. Hahn, 'I "gentili” e "un uom nasce a la riva / de l'Indo" (Par. XIX, vv.70 sqq.)', L'Alighieri. Rassegna bibliografica dantesca 18 (1977), 2, 3-8; D. Thomson, 'Dante's Virtuous Romans', Dante Studies 96 (1978), 145-62; R. Morghen, 'Dante tra l'“umano” e la storia della salvezza', in L'Alighieri. Rassegna bibliografica dantesca 21 (1980), 1, 18-30; N. Iliescu, 'Will Virgil be saved?', Mediaevalia 12 (1986), 93-114 and as 'Sarà salvo Virgilio?' in Dante. Summa medievalis. Proceedings of the Symposium of the Center for Italian Studies, SUNY Stony Brook, ed. by C. Franco and L. Morgan (Stony Brook (N.Y.): Forum Italicum, 1995), pp. 112-33; M. Allan, 'Does Dante hope for Vergil's Salvation?', Modern Language Notes 104 (1989), 1, 193-205; M. Picone, 'La "viva speranza” di Dante e il problema della salvezza dei pagani virtuosi. Una lettura di Paradiso 20', Quaderni di Italianistica 10 
we to account for this situation? Can it be a question, Kenelm wonders, of implicit faith, of the kind of faith which, lacking any specifically Christian content, is nonetheless sustained by a sense of the providentiality of it all and of what this might mean by way of a presiding deity? ${ }^{7}$ No, he says,

(1989), 1-2, 251-68; idem, 'Auctoritas classica e salvezza cristiana: una lettura tipologica di Purgatorio XXII', in Studi in memoria di Giorgio Varanini (Pisa: Giardini, 1992), vol. I (Dal Duecento al Quattrocento), pp. 379-95; T. Barolini, 'Q: Does Dante hope for Vergil's Salvation?', Modern Language Notes 105 (1990), 138-44 and 147-49 (subsequently in Dante and the Origins of Italian Literary Culture (New York: Fordham University Press, 2006), pp. 151-57); G. Cremascoli, 'Paganesimo e mondo cristiano nel commento a Dante di Benvenuto da Imola', in P. Palmieri and C. Paolazzi, Benvenuto da Imola, lettore degli antichi e dei moderni (Ravenna: Longo, 1991), pp. 111-25; B. D. Schildgen, 'Dante and the Indus', Dante Studies 111 (1993), 177-93; eadem, 'Dante's Utopian Political Vision, the Roman Empire, and the Salvation of Pagans', Annalid'Italianistica 19 (2001), 51-69; G. Muresu, 'Le "vie" della redenzione (Paradiso VII)', Rassegna della letteratura italiana 98 (1994), 1-2, 5-19 (and in Il richiamo dell'antica strega. Altri saggi di semantica dantesca (Roma: Bulzoni, 1997), pp. 203-24); M. L. Colish, 'The Virtuous Pagan. Dante and Christian Tradition', in W. Caferro and D. G. Fisher (eds), The Unbounded Community. Papers in Christian Ecumenism in Honor of Jaraslov Pelikan (New York: Garland, 1996), pp. 43-91 (and in The Fathers and Beyond. Church Fathers between Ancient and Medieval Thought (Aldershot: Ashgate, 2008), pp. 1-40); P. Boitani, 'Cristianesimo e tradizione pagana', in Lo spazio letterario del Medioevo (Rome: Salerno, 1999-2005), vol. 2 (Il Medioevo volgare), pp. 181-204 (subsequently as 'Tradizione classica e tradizione cristiana', in Letteratura europea e medioevo volgare (Bologna: Il Mulino, 2007), pp. 21-43); N. Cacciaglia, "'Per fede e per opere" (una lettura del tema della salvezza nella Divina Commedia)', in Critica Letteraria 30 (2002), 2-3, 265-274 (also in Annali dell'Università per Stranieri di Perugia 29 (2002), 123-131); G. Cannavò (ed.), Regnum celorum vöolenza pate. Dante e la salvezza Jell'umanità. Letture Dantesche Giubilari, Vicenza, October 1999 - June 2000 (above), with A. M. Chiavacci Leonardi, 'La salvezza degli infedeli: il canto XX del Paradiso' at pp. 193203; B. Martinelli, 'Canto XIX', in Lectura Dantis Turicensis. Paradiso, ed. G. Güntert and M. Picone (Florence: Cesati, 2002), pp. 281-305 (revised with the title 'La fede in Cristo. Dante e il problema della salvezza (Paradiso XIX)', Rivista di Letteratura Italiana 20 (2002), 2, 11-39 and in Dante. L' "altro viaggio" (Pisa: Giardini, 2007), pp. 289-319); G. Inglese, 'Il destino dei non credenti. Lettura di Paradiso XIX', La Cultura. Rivista trimestrale di filosofia letteratura e storia 42 (2004), 2, 315-29; A. Lanza, 'Giustizia divina e salvezza dei 'senza fede', in Dante eterodosso (Bergamo: Moretti Honegger, 2004), pp. 113-24; C. O'Connell Baur, Dante's Hermeneutics of Salvation. Passages to Freedom in the 'Divine Comedy' (Toronto, Buffalo and London: University of Toronto Press, 2007). More generally on the soteriological issue, M. Frezza, Il problema della salvezza dei paganida Abelardo al Seicento (Naples: Fiorentino, 1962); R. V. Turner, “Descendit ad Inferos”. Medieval Views on Christ's Descent into Hell and the Salvation of the Ancient Just', Journal of the History of Ideas 27 (1966), 173-94.

7 Thomas, ST at IIa IIae.2.7 ad 3: 'Ad tertium dicendum quod multis gentilium facta fuit revelatio de Christo, ut patet per ea quae praedixerunt. Nam Iob XIX dicitur, "scio quod redemptor meus vivit". Sibylla etiam praenuntiavit quaedam de Christo, ut Augustinus dicit. Invenitur etiam in historiis Romanorum quod tempore Constantini Augusti et Irenae matris eius inventum fuit quoddam sepulcrum in quo iacebat homo auream laminam habens in pectore in qua scriptum erat, "Christus nascetur ex virgine et credo in eum. O sol, sub Irenae et Constantini temporibus iterum me videbis". Si qui tamen 
this will not do, for given the notion of implicit faith as a gift to theologians in moments such as this, Dante seems not to have heard of it:

Now it had always been accepted in the Church that the Old Testament was the record of the first stage in God's self-revelation to mankind; and, by the same token, of a kind of inchoate faith in the Christ to come on the part of the pious Jews. And this reading of the Bible was expressed theologically by speaking of faith in Christ as passing through stages of gradually increasing explicitness. Foreshadowings of Christianity were also looked for in the records of paganism, though less seriously and systematically. Still, since Dante himself looked in that direction for 'prophecies' of Christ - taking the Sibylline oracles, for example, to be such, as so many medieval Christians did - one might expect to find some suggestion in the Comedy that pagans too might be saved by an implicit faith in Christ analogous to that of the Hebrew patriarchs and prophets. But it is hard to find even a hint of this. Indeed, apart from the Jewish heroes and heroines whom Virgil saw being led out of Limbo by Christ in person after his Passion, there seems to be no certain case of merely implicit faith in Christ in the whole Comedy. (p. 177) 8

salvati fuerunt quibus revelatio non fuit facta, non fuerunt salvati absque fide mediatoris. Quia etsi non habuerunt fidem explicitam, habuerunt tamen fidem implicitam in divina providentia, credentes Deum esse liberatorem hominum secundum modos sibi placitos et secundum quod aliquibus veritatem cognoscentibus ipse revelasset, secundum illud Iob XXXV, "qui docet nos super iumenta terrae".' Thus with reference to Cornelius in Acts 10:4, ibid. IIa IIae.10.4 ad 3: 'Ad tertium dicendum quod per infidelitatem non corrumpitur totaliter in infidelibus ratio naturalis, quin remaneat in eis aliqua veri cognitio, per quam possunt facere aliquod opus de genere bonorum. De Cornelio tamen sciendum est quod infidelis non erat, alioquin eius operatio accepta non fuisset Deo, cui sine fide nullus potest placere. Habebat autem fidem implicitam, nondum manifestata Evangelii veritate. Unde ut eum in fide plene instrueret, mittitur ad eum Petrus.' William of Ockham, in the Dialogus (pt 1, bk 4, ch. 3), has: 'Hoc per exemplum de Cornelio centurione de quo habetur Actuum 10 c. patere videtur. Qui antequam de Christo fidem haberet explicitam fuit fidelis quia iustus et timens Deum et per consequens fidem habuit saltem implicitam. Et ita fides implicita sufficit ad hoc quod aliquis sit catholicus et fidelis', etc.

${ }^{8}$ See too p. 185: 'The conclusion then seems clear, that while Dante allows in principle for the salvation of pagans, he represents this, in his poem, as extremely exceptional; not necessarily so, perhaps, in respect of the number of pagans who might be saved, but certainly in respect of the way they may be saved. For this way must be by an explicit faith in Christ; which, in the two cases described by Dante, required the working of miracles. Thus the episode would seem to show that for Dante grace and the faith that lays hold of it was emphatically not available to all men through the ordinary workings of Providence; or at least it had nothing of that "normality" which we nowadays tend to attribute to it by extending to the utmost the concept of implicit faith. Medieval theology possessed this concept, but did little with it; Dante seems hardly aware of it.' G. Whatley, 'The Uses of Hagiography: the Legend of Pope Gregory and the Emperor Trajan in the Middle Ages', Viator 15 (1984), 25-63. 
If not, then, of implicit faith, can it be a question of negative unbelief, of the kind of unbelief proper to those knowing no better? No, says Kenelm, neither will this do, Virgil, anxious as he is to confirm the collective innocence of the noble pagans (the 'ei non peccaro' of Inf. IV.34), ${ }^{9}$ admitting as far as he personally is concerned to an element of recalcitrance, to his having rebelled against the law of God (the 'perch' i' fu' ribellante a la sua legge' of Inf. I.125). How, therefore, given the disqualification both of implicit faith and of negative unbelief as ways around the problem of pagan righteousness and reprobation, are we to account for Dante's position here, for his concern to separate out the noble spirits of antiquity and to make a special case of them? The answer, Kenelm thinks, lies deep within him, for piety, in Dante, is always challenged by paganism, by a counter-commitment to Aristotle - not Peter, Paul, Augustine, Bernard, Thomas or even Christ himself, but Aristotle - as spokesman for properly human happiness here and now; so, for example, to look back for a moment to the Convivio, these lines from Book IV (vi.7-16), secure in their sense of the Ethics as a point of arrival in the area of moral philosophy:

Veramente Aristotile, che Stagirite ebbe sopranome, e Zenocrate Calcedonio, suo compagnone, [per lo studio loro], e per lo 'ngegno [eccellente] e quasi divino che la natura in Aristotile messo avea, questo fine conoscendo per lo modo socratico quasi e academico, limaro e a perfezione la filosofia morale redussero, e massimamente Aristotile. E però che Aristotile cominciò a disputare andando in qua e in lae, chiamati furono - lui, dico, e li suoi compagni Peripatetici, che tanto vale quanto 'deambulatori'. E però che la perfezione di questa moralitade per Aristotile terminata fue, lo nome de li Academici si spense, e tutti quelli che a questa setta si presero Peripatetici sono chiamati; e tiene questa gente oggi lo reggimento del mondo in dottrina per tutte parti, e puotesi appellare quasi cattolica oppinione. Per che vedere si può, Aristotile essere additatore e conduttore de la gente a questo segno.

(Conv. IV.vi.15-16) $)^{10}$

${ }^{9}$ [Now, before you go farther, I will have you know] that they did not sin. Purg. VII.7-9 and 25-36: “'Io son Virgilio; e per null' altro rio / lo ciel perdei che per non aver fé”. / Così rispuose allora il duca mio. / ... / "Non per far, ma per non fare ho perduto / a veder l'alto Sol che tu disiri / e che fu tardi per me conosciuto. / Luogo è là giù non tristo di martìri, / ma di tenebre solo, ove i lamenti / non suonan come guai, ma son sospiri. / Quivi sto io coi pargoli innocenti / dai denti morsi de la morte avante / che fosser da l'umana colpa essenti; / quivi sto io con quei che le tre sante / virtù non si vestiro, e sanza vizio / conobber l'altre e seguir tutte quante".'

${ }^{10}$ However, it was Aristotle (surnamed the Stagirite) and his noted companion Xenocrates of Chalecedon, who, thanks to the unique - one might say divine-intelligence 
while as far as the Commedia is concerned, these from Inferno IV, no less complete in their commitment to the philosopher as the master of those who know and thus, once again, as the guide to a certain kind of properly human happiness:

Poi ch'innalzai un poco più le ciglia, vidi 'l maestro di color che sanno seder tra filosofica famiglia.

Tutti lo miran, tutti onor li fanno: quivi vid' ïo Socrate e Platone, che 'nnanzi a li altri più presso li stanno.

(Inf. IV.130-35) ${ }^{11}$

Now Thomas, Kenelm notes, is more circumspect, the Ethics for him pointing to a species of happiness, not sufficient unto itself and thus qualitatively distinct in respect of what comes next, but merely proportionate to our circumstances here and now. Not so, however, Dante, who, inclined as he was to read with a dash of enthusiasm, saw in it a recipe for perfect happiness - or for perfect happiness, at any rate, of a certain sort - this side of death. True, there is more to come, but what awaits us in the next life must be something other than what we have or can have in this life, something not merely buman but more than buman in kind - a notion which, taken up in the Convivio and the Monarchia for the purposes of resolving a set of 'high-level' concerns in the areas of moral philosophy and political theology, subsists both into the Dantean limbo and into the fabric generally of the first canticle of the Commedia. With this, then, we are home, Dante, even here, being captive to an antique but still powerfully insistent habit of mind. True, he is no Boethius of Dacia with, in the De summo bono, his state-of-the-art essay

with which nature had endowed Aristotle, refined moral philosophy and brought it to perfection through pursuing their study of this end by much the same method as Socrates and the Academics; in this, Aristotle played the major role. Since he began to hold public disputations during which he walked up and down, he and his companions were called Peripatetics, or 'people who walk around'. Since it was Aristotle who brought this doctrine to its final perfection, the name 'Academics' was eclipsed, and all who adhered to this school of thought were called Peripatetics. Today, the teaching of this group holds sway everywhere, and may almost be said to be the universal opinion. It is evident, therefore, that Aristotle has directed and led people to the goal we have been discussing. Cf. Conv. II.v.7: 'Queste oppinioni sono riprovate per false nel secondo De Celo et Mundo da quello glorioso filosofo al quale la natura più aperse li suoi segreti ..., etc.

${ }^{11}$ When I raised my eyes a little higher, I saw the Master of those who know, seated in a philosophic family. All look to him, all do him honour. There, nearest to him and in front of the rest, I saw Socrates and Plato. 
on the Aristotelian 'model man.'. ${ }^{12}$ But neither is he a Thomas Aquinas, with, in the Prima secundae, his no less state-of-the-art meditation on the referability of each and every righteous inflexion of the spirit to a prior movement of grace as its point of departure; ${ }^{13}$ for Dante's, even into the

12 p. 219, with, a little further down on that page: 'Now, probably neither of these texts I have glanced at - almost certainly not the De Summo Bono - would have met with Dante's entire approval; not even when writing the Convivio. But they are, I think, extremely indicative of a temper, an approach, a way of thinking about and formulating the situation of man on earth without which neither Convivio IV, nor Monarchia III.xv, nor the Dantean Limbo would in fact have been possible. What had emerged here and there in the West was the conception of a humanist ethic based more or less exclusively on the "natural order" - of an area of human activity that would be self-contained and autonomous; virtually independent of grace whether elevans or sanans. It was against just such a conception that the Augustinian Petrarch was later fiercely to react; but in the meantime it had deeply affected the Aristotelian Dante.' For the De summo bono of Boethius of Dacia, M. Grabmann, Mittelalterlisches Geistesleben: Abbandlungen zur Geschichte der Scholastik und Mystik (München: Hueber, 1936), vol. 2, pp. 200-24, and, for the Quaestio de felicitate of James of Pistoia, Medioevo e Rinascimento. Studi in onore di B. Nardi (Florence: Sansoni, 1955), vol. 2, pp. 427-63. E. Gilson, 'Boèce de Dacie et la double vérité', Archives J'bistoire doctrinale et littéraire du moyen âge 22 (1955), 81-99, and on James of Pistoia, P. O. Kristeller, 'A Philosophical Treatise from Bologna dedicated to Guido Cavalcanti: Magister Jacobus de Pistorio and his "Questio de felicitate"', Medioevo e Rinascimento (above), vol. 1, pp. 425-63. More generally, M. Grabmann, 'L'aristotelismo italiano al tempo di Dante con particolare riguardo all'Università di Bologna', Rivista di filosofia neoscolastica 38 (1946), 260-77; C. I. Ermatinger, 'Averroism in the Early Fourteenth Century', Medieval Studies 16 (1954), 35-56; A. Maier, 'Die Bologneser Philosophen des 14. Jahrhunderts', Studi e memorie per la Storia dell'Università di Bologna, new series, 1 (1956), 299-312; M. Corti, Dante a un nuovo crocevia (Florence: Sansoni, 1982).

${ }^{13}$ ST Ia IIae.109.2 resp.: 'natura hominis dupliciter potest considerari, uno modo, in sui integritate, sicut fuit in primo parente ante peccatum; alio modo, secundum quod est corrupta in nobis post peccatum primi parentis. Secundum autem utrumque statum, natura humana indiget auxilio divino ad faciendum vel volendum quodcumque bonum, sicut primo movente, ut dictum est. Sed in statu naturae integrae, quantum ad sufficientiam operativae virtutis, poterat homo per sua naturalia velle et operari bonum suae naturae proportionatum, quale est bonum virtutis acquisitae, non autem bonum superexcedens, quale est bonum virtutis infusae. Sed in statu naturae corruptae etiam deficit homo ab hoc quod secundum suam naturam potest, ut non possit totum huiusmodi bonum implere per sua naturalia. Quia tamen natura humana per peccatum non est totaliter corrupta, ut scilicet toto bono naturae privetur; potest quidem etiam in statu naturae corruptae, per virtutem suae naturae aliquod bonum particulare agere, sicut aedificare domos, plantare vineas, et alia huiusmodi; non tamen totum bonum sibi connaturale, ita quod in nullo deficiat. Sicut homo infirmus potest per seipsum aliquem motum habere; non tamen perfecte potest moveri motu hominis sani, nisi sanetur auxilio medicinae. Sic igitur virtute gratuita superaddita virtuti naturae indiget homo in statu naturae integrae quantum ad unum, scilicet ad operandum et volendum bonum supernaturale. Sed in statu naturae corruptae, quantum ad duo, scilicet ut sanetur; et ulterius ut bonum supernaturalis virtutis operetur, quod est meritorium. Ulterius autem in utroque statu indiget homo auxilio divino ut ab ipso moveatur ad bene agendum' notable for its sense of autonomy as stretching, strictly speaking, only to matters of moral 
Commedia, is a separating out of these things, a distinction between them for the purpose of recognizing and of rejoicing in their perseitas, this, in fact, being Kenelm's point of arrival in these essays, the point-towardswhich of his troubled meditation:

From all the above, in any event, we may conclude, I think, that Dante shows a marked tendency, through the Convivio and the Monarchia and even in the Comedy, to reduce to a minimum the conceivable contacts between human nature and divine grace; even if we are persuaded, by the evidence adduced in the last few pages, or on other grounds, that he did allow a bare possibility of such contact for all adult human beings. And that tendency, with its consequences, is what I have taken as characteristic of the 'other', the second Dante implied in the title of this essay. And perhaps it reveals an important defect, from the Christian point of view, in this great Christian's thinking about man: an over-readiness to conceive of moral virtue in isolation from Charity, 'the first and greatest commandment'. After all, a certain practice and cult of moral virtue is quite compatible with the radical perversity of indifference to God. But Christianity requires that the moral virtues themselves be offered to God as a way - as the way - of cooperating with his grace. In this perspective the natural virtues themselves, ordered under Charity ('the mother of the virtues'), become as it were organs of grace, are no longer just humanly 'acquired' but divinely 'infused'. Guided by this insight St Thomas could take over the whole achievement of Aristotle, as a philosophical moralist, while giving it an entirely new setting and direction. In Dantean terms this means the difference between Limbo and the Purgatorio; in which we see repentant man recovering, under

indifference ('building houses, planting vines, and the like'); De ver. 24.14 passim, etc. On Dante and Thomas, B. Nardi, Nel mondo di Dante (Rome: Edizioni di Storia e Letteratura, 1944); idem, Saggie note di critica Jantesca (Milan: Ricciardi, 1966); idem, Saggi di filosofia dantesca, 2nd edn (Florence: La Nuova Italia, 1967); idem, Dante e la cultura medievale, ed. P. Mazzantini with an introduction by T. Gregory (Rome: Laterza, 1983, originally Bari: Laterza, 1942); idem, Dal 'Convivio' alla 'Commedia': sei saggidanteschi, with a preface by O. Capitani (Rome: Nella sede dell'Istituto, 1992, originally 1960); E. Gilson, Dante and Philosophy, trans. D. Moore (New York: Harper and Row, 1963; originally Dante et la philosophie (Paris: Vrin, 1939), second edn 1953). In Kenelm himself, see especially The Mind in Love, Aquinas Society of London 25 (London: Blackfriars, 1956, and in J. Freccero (ed.), Dante. A Collection of Critical Essays (Englewood Cliffs, N.J.: Prentice Hall, 1965), pp. 43-60); 'The Tact of St Thomas', in God's Tree: Essays on Dante and Other Matters (London: Blackfriars, 1957), pp. 141-49; 'Religion and Philosophy in Dante', in The Mind of Dante (Cambridge: Cambridge University Press, 1965), pp. 47-78; 'Tommaso d'Aquino', in the Enciclopedia Jantesca, 6 vols (Rome: Istituto della Enciclopedia Italiana, 1970-78), vol. 5, pp. 626-49; Dante e San Tommaso (Rome: Casa di Dante, 1975; lecture of 17 November, 1974 at the Casa di Dante in Rome). 
grace, the lost or diminished natural virtues, but only in preparation for something that is utterly beyond their own range, a love-union with the Infinite. In the Purgatorio Aristotelianism is integrated into Christianity; in the Dantean Limbo it is not. (pp. 252-53)

In the event, the passage is as troubling as it is troubled; for in the degree to which Dante was himself aware of the tensions at work deep within him (a situation confirmed in the course of his encounter with Beatrice in the earthly paradise), then his courage in seeking to address and as far as may be to resolve this situation by way of the fresh mechanism of the Commedia - by way of what we have described and shall describe again as the twofold theologism and theatricality of the text - is all the more impressive, all the more likely to confirm us in a sense of his having at last come of age as a theological spirit. How far Kenelm himself was persuaded of this I cannot be sure, for I remember his asking me a shade anxiously what, soon after its publication, I thought of the Two Dantes volume, to which I replied then as I would reply now that I was much impressed by it. But how far this was anxiety in respect of precisely this issue, as distinct from matters arising from the book generally, I cannot say.

4. What, then, are we to make of the two Dantes thesis, of Kenelm's account of Dantean spirituality - by which we mean the mature spirituality of the Commedia - as, if not captive to, then at any rate detained by its pagan component? The first thing to say is that there can be no underestimating, still less any denying, what Kenelm describes as the 'humanistic' element of that spirituality, just as there can be no denying the way in which, in key moments both of natural- and of moral-philosophical clarification (Virgil's account of the structure of hell in Canto XI of the Inferno for example), this element subsists into the Commedia. But by the same token there can be no passing over either (a) the way in which Dante is careful to bring home the moral and metaphysical moments of the argument to their theological ground, to what actually matters about them in respect of the soul's journey into God, or (b) the care with which he distributes the alternative voice with a view to its neutralization as a principle of instability in the poem. Taking, then, the first, of these things we may say that while there is much to be said for seeing and interpreting hell in terms of its unreasonableness, there can be no question of its being exhausted by this, for unreason, within the economy of the text generally, points on to something more serious than itself, namely to the the truth of separation from self and from God as the ground of its sinfulness and root of its effrontery, at which point its theological substance moves clearly into view. Now for Kenelm too unreason as a high-level inflexion of the spirit 
points on to something more serious than itself, namely, to ingratitude and lovelessness. But for all his discerning in the depths of unreason its status as a matter of impiety, he remains unwilling to develop his sense of this first canticle of the poem in terms of its specifically Christian content, preferring instead to look in the direction of its Peripatetic component, of its accountability, less to the gospels, than to the Philosopher; so, for example, these lines from his introduction to the 1961 Warwick Chipman translation of the Inferno, oddly reluctant in its endorsement of the 'religious' as distinct from the philosophical substance the text:

And the sin he encounters on his way is, I repeat, largely sin against the light of reason alone, apart from any 'higher' considerations. It is wrongdoing very much on the human level and in the give and take of ordinary social discourse. A strong social emphasis marks the Inferno; and, since the poet was deeply involved in politics and his world was that of the medieval commune, the more or less selfgoverning city-state, a strong political emphasis too. It is true that all wrong-doing, however social or political its circumstances, had for Dante a deep religious significance. Since human nature is God's creation, to injure man is to offend God. And certainly the Inferno could only have been written by a believing Christian. Nevertheless the measure of right and wrong that governs, immediately, the greater part of it is a rational, not a specifically Christian, measure; it is drawn from moral philosophy (especially Aristotle) rather than from the Gospels. ${ }^{14}$

Now the Inferno - the Inferno, perhaps, more than either the Purgatorio or the Paradiso - is a canticle of layered consciousness, both of surface and of deep awareness, and there can be no gainsaying the presence of Aristotle at the first of these levels, at the point of moral-philosophical elucidation. And neither can there be any gainsaying Dante's preoccupation in the Inferno with the socially detrimental character of sin as a matter of separation in the depths, with its power, not only to destroy the sinner, but, in destroying him, to separate out one man from another and thus to shatter the unity of the Spirit and the bond of peace. Unreason, therefore, both in itself and as a matter of social annihilation is everywhere in the text and everywhere decisive for its interpretation. But - and this now is the point - layered as it is in consciousness, and this in such a way as to free the text for the development of this or that discrete emphasis, each layer of awareness, within the economy of the whole, remains transparent

14 W. Chipman (trans), Inferno (London, New York and Toronto: Oxford University Press, 1961), p. xiii. 
to the others, invoking them as it does so for the purposes of a statement ultimately one in conception. Each, in other words, susceptible as it is to development in its own right and on its own terms, coalesces with the others to form a single and ultimately undifferentiated stratum of awareness, a movement of the spirit comprehending in a single sweep both its surface and its deep reasons, herein precisely lying the triumph of the Commedia as testimony to its inner consistency, to an overcoming in Dante of everything in him making for alternativism at the point of ultimate concern.

But that is not all, for in addition to the transparency of every surface emphasis in the text to the theological substance by which it is indwelt and in terms of which it stands ultimately to be interpreted, there is the kind of theatricality operative on the plane of the horizontal and responsible for ensuring over against the heterodox and thus disruptive voice the unity of what fundamentally is being said in the poem. Given, in other words, what amounts in the Commedia to its decorum, to Dante's distribution of the discordant voice, then the claim to moral innocence voiced by Virgil in Inferno IV or Purgatorio VII and all this implies by way of antique righteousness need not worry us; for Virgil, in insisting in the way he does upon his sinlessness, says what Virgil would say, indeed the only thing he can say. Now here again we have to be careful, for Kenelm, himself alert to the nature of the text as drama, is as sensitive as any to the particularity of the Virgilian utterance, to Virgil's speaking out of the properties of personality as reconstructed by Dante in his poem; so, for example, from the Chipman translation of the Inferno mentioned a moment ago, these nicely calibrated remarks on the difference as far as the Dantean Virgil is concerned between knowing Christianity and merely knowing of it or about it:

This 'Virgil' believes in God. He knows that an original goodness glows through all creation; moreover he knows how creatures can deny and dishonour that Goodness and besmirch and violate its effects, particularly the noblest effect of which man has experience, his own rational nature. Virgil even knows something of the fall of the angels. "Behold Dis", he says at the end, pointing to Satan; and we can suppose that he, like his pupil, knew that it was through pride that "he who was so fair ... raised his brow against his Maker". He is aware too of the Church even if, in the great ecclesiastical Canto XIX, he will tactfully step aside and leave that unforgettable indictment of clerical materialism to flow from Catholic lips. But Virgil only knows of the Christian revelation, he has not personally received it; and though familiar with the topography of Hell, there is something about 
damnation itself that always escapes him. No wonder; never having known God incarnate, how can he understand a condition which is only definable as the consequence of a rejection of that God? ${ }^{15}$

to which, from the Two Dantes, we might add these on Virgil's particular kind of piety in the poem, piety yes, but piety at a remove, lived out at a distance from the real thing:

Virgil's own kind of piety is a fact entwined in the narrative of the Inferno and Purgatorio, more or less visible as the occasion requires. It is always in character; never Christian, always at a certain remove, like his discernment of those points of doctrine which he has to leave to Beatrice to instruct Dante in. ${ }^{16}$

Kenelm's too, therefore, is a sense of Dante's decorum, of his proceeding by way of what might reasonably be expected of his characters. But and this now is the point - for all his discerning in this respect, he is not averse to lifting that same Virgil from the context in which Dante has so carefully placed him with a view to fashioning from him an alter ego or alternative self functioning in the poem as a principle of disruption, as tending, not merely to differentiate, but to damage and ultimately to destroy its consistency as a specifically Christian utterance. True, by the time we reach purgatory there is something of a recovery, a fresh sense of how one thing stands to be integrated with another, the Aristotelian with the Christian and the pagan with the pious. But by the time we reach purgatory we are a good third of the way into it, our sense of the shape and structure of the poem having long since crystallized. Now it may be that neither transparency nor theatricality, taken alone, is enough to do anything about this, transparency coming in degrees, and theatricality never above privileging one party in particular as spokesman for the author. Taken together, however, they are just about invincible, for operative as they are on the planes respectively of the vertical and of the horizontal they comprehend absolutely the space they describe, every contingency in the area of thought and expression. Operative as they are on the twin axes of awareness, they carry all before.

15 Inferno (previous note), p. xiv.

16 The Two Danted (note 1 above), p. 244. 